\title{
MÄNG JA VALU XXI SAJANDI TEISE KÜMNENDI LEEDU ROMAANIS
}

\author{
TIINA KATTEL
}

$\mathrm{L}$ eedus raamatupoodides käies avaneb üsna tuttavlik pilt: raamatute hulk aina kasvab, palju avaldatakse nii algupärast kui ka tõlkekirjandust. Pilt on kirev ja valik seinast seina. Kirjutavad kõik ja kõigest. Kirjastustest saadud andmete järgi ilmub aastas keskmiselt 600-700 uut ilukirjandusteost, millest umbes 450 on leedu autorite looming. Nii suuremahuline produktsioon teeb nii lugeja kui ka kriitiku elu raskeks, kõigega lihtsalt ei jõua puhtfüüsiliselt kursis olla, kõigele ei jõua hinnangut anda ja valikuid on raske teha. Ometi joonistuvad välja suundumused ja tõusevad esile mõningad autorid ning teosed. Leedu juhtiv kirjandusajakiri Metai (Aasta; meie Loomingu analoog) korraldab iga aasta alguses kriitikute ja kirjandusteadlaste ümarlaua, et võtta kokku möödunud aasta kirjanduselu. Läinudaastane jutuajamine avaldati Metai aprillinumbris ning seal tõdeb moderaator Regimantas Tamošaitis (2013: 69), et „on jäänud mulje, et leedu lugeja hakkab aina enam austama oma autoreid, samas kui tõlkekirjandus tõmbub kuhugi eemale ja eksisteerib üsna universaalse, aga meid enam mitte häiriva kultuurilise foonina". Kirjandusega sina peal oleva seitsme inimese mõttevahetusest jääbki kõlama arvamus, et kasvab nii leedu autorite eneseusk kui ka usk lugejasse, nad kirjutavad innustunult, kirjutavad palju ja neid ei peata miski. Tänu sellele on leedu kirjandusse ilmunud uusi nimesid, teemasid ja žanre.

Levinud arusaama järgi on leedulased poeetide rahvas ning leedu kirjanduse raudvaraks on luule: „On kaldutud isegi väitma, et leedulase maailmasuhtumine on üldse lüüriline" (Ambrazevičius 1937: 453). Põhjuseks on toodud asjaolu, et leedulased lihtsalt ei oska luua huvitavaid, universaalseid, samas originaalseid süžeesid, seetõttu polegi proosa kunagi olnud leedu kirjanduse tugevaim külg. Selle põhjusi on omakorda otsitud rahva meelelaadist. Leedulased ise ei pea end just eriti lõbusaks rahvaks. Arvatakse, et leedulased rohkem töötavad ja kurdavad, kui puhkavad ja lahutavad meelt. Mõnusalt on sel teemal ironiseerinud tugeva sotsiaalse närvi ja kodanikutundega esseist ja mütoloog Gintaras Beresnevičius ühes oma essees, kirjeldades „leedu loomust" kui alalist Rūpintojèlise (see on spetsiifiline leedu mõtiskleva Jeesuse puukujuke) seisundit: „Ta muretseb, istub ja muretseb. See muretsemine võib olla sõnatu ja põhimõtteliselt mõttevaba. See on olek. Ehk tõesti on see meditatsiooni leedu variant. [---] Siiski ei tundu see mure objektiviseerituna - murena konkreetsete asjade pärast” (Beresnevičius 2002: 107).

Ehk osalt seetõttu on krestomaatilise leedu proosa jutustamisstiil aeglane ja igavavõitu, pole piisavalt sündmusi ega seiklusi. Leedu kirjandusteadlane Vytautas Kubilius pidas Jaan Krossi romaani „Paigallend” leedukeelse tõlke esitlusel 2003. aastal kõne, kus muuhulgas ütles: „Ma olen ikka ja alati imestanud, miks leedulastel, kes lõid omal ajal Läänemerest Musta mereni ulatuva võimsa riigi, pole olemas nüüdisaegse kõlaga ajaloolist romaani...., aga eestlased, kel polnud oma riiki kuni XX sajandi alguseni, ekspordivad niisugust 
romaani kaugele Läände" (Kubilius 2004: 295). On ka öeldud, et Leedus puudus tugev ja pikaajaline meelelahutusliku kirjanduse traditsioon, sest sellise kirjanduse tekkeks polnud tingimusi (leedukeelse kirjasõna keeld aastatel 1864-1904, proosa hiline areng, kirjanduse pidev kohustus teenida sotsiaalseid või rahvuslikke ideaale, kultuuri enesekaitse okupatsioonirežiimide eest jne). Leedu proosas nappis siiani artistlikkust, žanrilist mitmekesisust, väljenduse elegantsi - seda, mida viimastel aastatel on kuhjaga tekkinud. Loreta Mačianskaitè (2010: 114) on öelnud, et lüürilisele leedu proosa traditsioonile on pikka aega olnud omane kannatamise sündroom (ld kentẹjimo sindromas), seda ka pärast taasiseseisvumist. Sama meelt on Jūratė Sprindytė, kes möödunud aasta oktoobris Druskininkais leedu ilukirjanduse tõlkijate seminaril väitis, et leedu parimad, hinnatuimad raamatud on valusad, traumaatilised, mittemeelelahutuslikud, mitte eriti mängulised, pigem kurvad kui optimistlikud.

Kuid pärast taasiseseisvumist on leedu romaani areng olnud tõeliselt tormiline ja põnev ning esimest korda on romaanil õnnestunud luule ja lühiproosa liidripositsioonilt tõrjuda. Üheks põhjuseks on kindlasti seegi, et just romaan on kõigist kirjandusžanridest enim seotud ühiskondliku eluga, tegu on avara ja mahuka proosavormiga, kus otsitakse vastuseid vastaval ajajärgul elanud inimeste jaoks olulistele küsimustele ja neid huvitavatele probleemidele. Taasiseseisvumise järel leedu kirjanduses aset leidnud olulisemaid muutusi tutvustas eesti lugejaile Almantas Samalavičius (2010) artiklis „Peaaegu normaalne”. Autor toob seal märksõnadena esile järgmist: kompromissitu ja šokeeriv, must huumor ning ühiskonnakriitika, maa ja linn. Iseenesest peavad need paika ka viimase viie aasta romaanidest rääkides. On nii avalikkust šokeerivat tabude murdmist kui ka ühiskonnakriitilisust. Samal ajal on maa ja linna vastandus mõnevõrra tagaplaanile vajumas. Kui veel kümmekond aastat tagasi väideti, et leedu proosa kanoonilise traditsiooni mudel on alati olnud üsna konservatiivne, ja traditsiooniline leedulikkuse mudel seostus maaharija kultuuri ülistamisega ning hiljem selle hukkumise taganutmisega, siis on selgemast selgem, et tänapäeval ei keerle belletristika enam selle vastandpaari ümber. Kuigi leedu linnakirjandusel pole väga pikaajalist traditsiooni, siis muutub linn aina loomulikumaks miljööks.

Omalt poolt lisaksin siia loendisse veel ajaloo valgete laikude täitmise, Vilniuse teema, balansseerimise trauma ja mängu vahel. Kirjanduses näevad paljud loomeinimesed vahendit, mis peaks suutma mõjutada ühiskonna teadvust, murda kivistunud stereotüüpe. Leedus on paaril viimasel aastal hoogu kogunud diskussioonid ajaloolise mälu lünkade üle. Poleemika keskmes on tõsiasi, et pikka aega on ignoreeritud või teadlikult unustatud lausa sajandeid, aegu, kui Leedul pole leedulaste arvates hästi läinud. Leedu ajaloos nimetatakse kuldajaks Leedu suurvürstiriigi aega kuni Vytautas Suure surmani 1430. aastal. Leedu ajalugu on mütologiseeritud ning nagu mitmest läbiviidud uuringust välja tuleb, siis esile tõstetakse vaid üksikuid (plussmärgiga) isikuid või sündmusi: riigi asutaja kuningas Mindaugas, Vytautas Suure Leedu (riigipiirid Balti merest Musta mereni), Žalgirise lahing. Vytautasest edasi on justkui tühjus ning siis tuleb taasiseseisvumine aastal 1918. Ühes uuringus küsiti ka seda, mille üle uhkust tunda Leedu XX sajandi ajaloos, ning vastuseks saadi - kangelaslik metsavendade võitlus ja teletorni kaitsmine 13. jaanuaril 1991. Leedulased ei näi justkui taipavat, kui võimas ajalugu neil on. Seda „auklikku” minevikku püüavad nüüd täita kirjanikud. 
Taasiseseisvumise aegadel tekkis Nõukogude okupatsioonist, küüditamistest ja sõjajärgseist aastaist rääkivate raamatute uputus, enamasti oli tegu mälestustega. Memuaarkirjanduse tohutu hulk tõi kaasa stereotüüpide laialdase leviku: Leedu kui „ümberpiiratud kindlus” ida ja lääne ristteel, leedulane kui ajaloo ohver. Pidev kangelaste ja vaenlaste otsimine, kaitsepositsioonil olek, ajaloolise tõe eitamine ja väide „nemad tegid” sünnitasid palju mustvalgeid lähenemisi. Kõik see kokku lõi ühiskonnas uued tabud, kivistunud hoiakud teatud ajaloosündmuste suhtes ning kujundas kollektiivset mälu. Nii tekitas üldiste hoiakutega vastuvoolu ujunud kirjanike looming suuremaid ja väiksemaid skandaale; stereotüüpe murda oli ja on raske. On öeldud, et leedu kirjandus ja ajalugu sattusid pideva vaenlaste vastu peetava võitluse ja kangelasliku kannatuse kujutamise pantvangi. Nii võis pühaks ja puutumatuks kuulutatud metsavendadest kirjutada vaid kui kangelastest, mitte kui tavalistest inimestest kõigi nende puudustega, või polnud hea toon tuua päevavalgele leedulaste osalus juutide massihävitamises, kui üldse, siis ikka senistest arusaamadest lähtuvalt ja eelkõige dokumentaalselt - „ausalt”. Võib öelda, et viimastel aastatel peavad mitmed leedu kirjanikud võitlust kivistunud banaalsuste vastu. Lähemast ja kaugemast ajaloost otsitakse huvitavaid sündmusi, nähtusi ja protsesse, mis annaksid uusi tõlgendusvõimalusi ja vaatepunkte minevikule.

Uus nähtus leedu kirjanduses on autorid, keda võib nimetada uusemigrantideks. Nad elavad ja töötavad väljaspool Leedut, kuid kirjutavad leedu keeles ja Leedu lugejale. Üldistuste tegemiseks on uusemigrantide põlvkond veel liiga lühikest aega eksisteerinud, kuid mingeid ühisjooni saab siiski esile tuua. Kuigi neis romaanides poetiseeritakse sageli nomaadlust, siis ometi kumab neist läbi koolipõlves omandatud ühine kirjanduslik, kultuuriline, ajalooline taust, side kodumaaga. Kangelased võivad küll naeruvääristada rahvuslikke ikoone, leida õnne ja eneseteostuse mujalt, ent nad ei ole siiski sajaprotsendiliselt maailmakodanikud. Ikka ilmub teksti siduv vihje või viide Leedule. Nii omandab mõni kindel koht erilise tähenduse (üsna sageli on selleks Vilnius, kus näiteks kogeti esimest armastust). Enam pole pagulaskirjandusele omast kodumaaigatsust, on ju tänapäeva emigrantidel vaba voli igal hetkel naasta, pigem on tegu konkreetse koha külge kasvamisega.

Käesolevas artiklis lähemalt tutvustatavate konkreetsete teoste ja autorite valiku aluseks on eelkõige minu kui lugeja subjektiivne sümpaatia, aga ka teatav „sotsioloogiline baas": heatahtlikud või soosivad retsensioonid, artiklid, preemiad, mitmesugused arutelud, iga-aastased parimate raamatute valimise andmed, tõlgitavus (mis võiks huvi pakkuda ja olla mõistetav mitteleedulasest lugejale, kes ei tunne autoreid, ei tea, mida kirjanikelt oodata, ei mõista alltekste ega peidetud vihjeid).

\section{Leedu kirjanduselu elavdav Vilniuse raamatumess}

Artikli alguses toodud väite - leedu lugeja eelistab omamaist kirjandust reaalsuseks saamisele on eelkõige kaasa aidanud kaks sündmust: iga-aastane rahvusvaheline Vilniuse raamatumess ning aasta parima raamatu konkurss. Kirjanduspreemiaid on Leedus loomulikult palju, kuid kohtumistelt kirjanikega on jäänud mulje, et kõige enam hindavad nad just seda, kui nende teos va- 
litakse aasta parima raamatu nominentide hulka, või mis veel parem, ka saab selle ihaldatud tiitli. Kindlasti on üheks põhjuseks see, et siin teevad valiku kirjanduselu eksperdid ja lugejad koos. Teisalt aga garanteerib see muidugi müügiedu.

Vilniuse raamatumessi (Vilniaus knygu mugé) korraldatakse alates 2000. aastast. Võib julgelt väita, et Vilniuse raamatumess on Leedu kultuuriaasta suursündmus, mida kinnitab ka külastajate arv: kui esimesel aastal küündis see 30 000, siis 2012. aastal juba 64000 inimeseni. Raamatumessil antakse alates aastast 2005 üle ka möödunud aasta parima raamatu preemia kolmes kategoorias: laste-, noorte- ja täiskasvanuteraamat. Kampaaniat, mis 2006. aastast kuulub ka valitsuse kinnitatud lugemise edendamise programmi, korraldavad Leedu riiklik raadio ja televisioon, kultuuriministeerium ja M. Mažvydase nimeline rahvusraamatukogu. Ekspertide komisjon valib välja viis raamatut, mida kogu kampaania käigus aktiivselt meedias tutvustatakse ja reklaamitakse. Kõigil soovijail on võimalik anda oma hääl kampaania kodulehel. Ja eesmärk tundub olema igati täidetud: lugejad tunnevad tõesti rohkem huvi nii üleüldse raamatute kui ka konkreetsemalt nüüdisaegse leedu kirjanduse vastu.

\section{Vilniuse müüt ja maagia}

Pealinn Vilnius kas lihtsalt tegevuspaiga või sümbolina on alati olnud leedu ilukirjanduses oluline, kuid muutunud on nii Vilniuse tähendus, roll kui ka kujutamislaad. Mõningase liialdusena võiks öelda, et peaaegu igal endast lugupidaval leedu kirjanikul on oma Vilnius. Kaks uuema leedu ilukirjanduse märgilist Vilniuse kujutist pärinevad kahelt põlvkonnakaaslaselt: Ričardas Gaveliselt (1950-2002) ja Jurgis Kunčinaselt (1947-2002). Mõlema autori loomingust tõstetakse esile romaane, kus Vilniuse roll on kaugelt suurem kui vaid tegevuspaik. Gavelise kultuslik totalitaarvõimu olemust ja sellest sündinud inimtüüpi lahkav romaan „Vilniaus pokeris” („Vilniuse pokker”) ilmus 1989. aastal ning selles kafkalikuks peetud teoses on Gediminase tornist, kunagisest linna ja rahvuse südamest, saanud paks impotentne fallos, mida nimetatakse „kastreeritud linna”, „kastreeritud Leedu” sümboliks. Vilniuse linna - sureva looma, kastreeritud ja jõuetu olendi, fataalse labürindi mütoloogiat arendab Gavelis oma teisteski teostes. Kunčinase 1993. aastal ilmunud armastusromaan „Tūla” fikseerib Brežnevi aja loojangu hulkuva kunstniku silmade läbi. Kunčinase romaanide ja jutustuste keskne teema ongi Vilniuse boheemlaste argipäev, tragikoomiline põgenemine tõeluse eest alkoholi abiga. Kunčinase Vilnius on kroonikakirjutaja Vilnius - tema põlvkonna nooruse hästi äratuntav linn. Erilist tähelepanu pöörab ta faktuurile, topograafilistele pisiasjadele: jäädvustatud on boheemlaste kooskäimise kohad, kohvikud ja õllekad, hotellid ja ühiselamud, ülikool ja Vilnelè jõekese kaldajärsakud, põiktänavad, väravad, majad, sildid, kaared, haiglad, pargid, väljakud, vanalinn, Užupis ja Žvèrynas jne.

Väidet, et Vilnius on leedu kirjanikele kaugelt enam kui vaid elupaik või tegevuskoht, kinnitab ajakirjas Nemunas avaldatud intervjuu Gavelisega, kes ütleb, et „Vilnius on lihtsalt maailma metafoor. Mulle on metafüüsiline Vilnius terve maailm, võib-olla isegi rohkem kui maailm. Seetõttu võib temast 
kirjutada lõpmatult. Pole üldse oluline, mida reaalne Vilnius minu reaalses elus tähendab. Tähtis on ainult Vilniuse müüt, tema maagia" (Vabuolas 1993: 27). Kui siia lisada müstika, on tulemuseks viimase viie aasta leedu romaani lühiiseloomustuse üks pool. Järgnevalt ülevaade mõningaist romaanidest, mis viimase viie aasta jooksul on esile toonud oma, teistsuguse Vilniuse-teema käsitluse.

Kui Kubilius 2004. aastal kurtis, et Leedus pole „nüüdisaegse kõlaga ajaloolist romaani”, siis nüüd on see olemas. Selle lünga täitis doktorikraadiga kunstiajaloolane ja ajakirjanik Kristina Sabaliauskaitè (snd 1975) kaheosalise ajaloolise romaaniga, mis sai väga vastaka vastuvõtu osaliseks. Romaanis „Silva Rerum” avaldab autor armastust Vilniusele ja tema ajaloole, nagu ta on ühes vestluses ka ausalt tunnistanud: „Vilnius on mulle kaasasündinud nagu DNA. See on minu kõige tugevamalt tuntav geograafiline identiteet. Vilniuse ilu joovastab, tema hädad teevad haiget. Kui hakkasin romaane kirjutama, sai sellest ka väljakutse kujutada neis sellist Vilniust, millist näen ja tunnen mina, rääkida tema dramaatilistest ajaloolistest hävitamise ja taassünni kihtidest” (Jablonskaitè 2012: 10-11). 2002. aastast päevalehe Lietuvos rytas väliskorrespondendina Londonis elav autor avaldas esikromaani „Silva Rerum” esimese osa 2008. aastal. Nüüdseks on sellest kümne kordustrükiga saanud viimaste aastate leedu ilukirjanduse bestseller number 1 , mis valiti 2009 . aastal parimaks raamatuks. Sama juhtus romaani järjega, 2011. aastal ilmunud teosega „Silva Rerum II”, mis valiti parimaks raamatuks 2011. aastal. Olgu öeldud, et Sabaliauskaitė teosed on ainsana kahel korral valitud aasta parimaks raamatuks.

Silva Rerum tähendab ladina keeles 'asjade metsa'; nii nimetati XVI-XVIII sajandil populaarset, põlvest põlve edasiantavat Leedu aadlike „pereraamatut”, kuhu peale selliste oluliste elusündmuste nagu sündide, pulmade ja surmade kuupäevade kirjutati ka sententse, luuletusi, kõnekäände, pidustustel öeldud tooste, tervituskõnesid ja panegüürikat. Romaani kesksed tegelased on Norvaiša (Narwoyszi) aadlisuguvõsa esindajad; esimese osa tegevusajaks on aastad 1659-1667, teise osa sündmused leiavad aset raskeil sõja-, nälja- ja katkuaastail 1707-1710. Teose vastuvõtt kriitikute poolt oli ja on kohati siiani üsna kriitiline, autorit süüdistatakse lugejaga manipuleerimises, uskumatu populaarsuse põhjusena nähakse eelkõige kavalat turundust ja head reklaami, mitte teose ilukirjanduslikku tugevust. Lisaks sellele, et autor lõi esimese leedu kirjanikuna korraliku leedu- ja ingliskeelse kodulehe (www.sabaliauskaite.com), on romaan edendanud ka Vilniuse turismielu: alates 2011. aasta 15. juulist hakkas Vilniuse turismiinfokeskus korraldama n-ö temaatilisi „Silva Rerumi” ekskursioone, mille marsruut läbib üheksat romaanis kirjeldatud ajaloolist kohta. Marsruudi koostas ja esimese ekskursiooni viis läbi autor ise.

Pärast Sabaliauskaitè kolmanda raamatu, novelli- ja jutustustekogu „Danielius Dalba \& kitos istorijos” („Danielius Dalba \& teised lood”, 2012) ilmumist on aga hakanud kostma arvamusi, et just see viimane raamat on banaalne, samal ajal kui ajalooline fiktsioon „Silva Rerum” oli muljetavaldav. Pärast ulatuslikku laitustelainet on irooniline lugeda, et kriitikud on „Silva Rerumi” ametlikult nimetanud viimase kümnendi üheks märkimisväärsemaks raamatuks. On ka väidetud, et kuna Leedus puudub ajalooliste romaanide kirjutamise ja lugemise traditsioon, siis ei osatud teosele reageerida ning suure müügiedu tõttu liigitati see lihtsalt kiiresti massikirjanduse hulka. Romaani 
välja andnud kirjastuse Baltos lankos peatoimetaja Agnė Jurčiukonytė (2009: 4) hinnangul „pole meil Leedus enam ammu või tegelikult pole ehk kunagi olnud nii tugevat ajaloolist romaani. Meie kirjastust hämmastas hetkel ebapopulaarse žanri renessanss Kristina Sabaliauskaitė teoses. See, et autoril õnnestus romaanis ühitada autentsed faktid, peredraama, Žemaitija ja Vilniuse kultuuriline olustik, anda edasi epohhi vaimu ja mis kõige olulisem - luua ka fataalse armastuse lugu, on vähimagi kahtluseta suure ande ja töö kinnitus. Kõik see on edasi antud nii haaravas stiilis, et ei jäta ükskõikseks ka neid, kellele XVII sajand huvi ei paku."

2012. aastal ilmus leedu kirjandusmaastikule täiesti uudne romaanižanr - metafiktsionaalne ajalooline detektiivromaan, Gina Viliūnè (snd 1974) „Karūna be karaliaus” („Kuningata kroon”). Vilniusest on küll palju kirjutatud, kuid kunagi varem pole seda tehtud Dan Browni „Da Vinci koodi” laadis. Romaani tegevustik leiab aset vaheldumisi mitmes ajaloolises ajas, kus tegelasteks kunagise Leedu suurvürstiriigi kantslerid, peapiiskopid ja Vilniuse arhitektid, ning tänapäevas, kus lootusetu töönarkomaan ja tüüpiline karjerist Algè Gustaitė peab ootamatult hakkama lahendama suurvürst Vytautas Suure krooni kadumise müstilist saladust. Romaan on enam kui kaasahaarav. Kuna autor on üle 10 aasta Vilniuses giidina tegutsenud ning varem avaldanud hobiajaloolasena raamatu Vilniuse pühakodadest, kasutab ta palju fakte, kuid oskab neid rüütada põnevate legendidega ja tegevustikku tuua autentsena mõjuvat olustikku. Raamatu tugevaim osa ongi minevikus toimuv, samas kui tänapäeva kantud detektiivlugu kipub kohati olema etteaimatav ning lihtsustatud. Autor on ühes intervjuus öelnud, et sai innustust romaani kirjutamiseks Londonist, kus teda raamatupoodides hämmastas Londoni ja Inglismaa ajaloost pajatavate romaanide arvukus ja žanriline mitmeküllus. Kindlasti on see teos huvitav lugemine kõigile, kes peavad lugu Vilniuse ja kogu Leedu suurvürstiriigi ajaloost.

Riigitelevisioonis kümme aastat produtsendi ja saatejuhina ametis olnud Andrius Tapinas (snd 1977) avaldas 2013. aasta algul oma esikromaani „Vilko valanda” („Hunditund”). Tapinas on kätt proovinud ka tõlkijana, tema leedunduses on ilmunud „Sõrmuste isanda” triloogia. Lisaks on tegemist eduka ärimehe ning andunud pokkerimängijaga. Nüüd aga üllatas ta lugejaid Vilniuse alternatiivajaloo, Leedu esimese aurupungi žanris kirjutatud romaaniga. Aurupunk (ingl steampunk) on ulme alamžanr, mida iseloomustavad aurumasinad ja mille tegevus toimub tihti XIX sajandi tööstusrevolutsioonist inspireeritud keskkonnas. Kõnealuse romaani tegevusaeg ja -koht on üsna täpselt määratletud - 1905. aasta Vilnius. Kuid siin kohtub lugeja Vilniusega, nagu see oleks võinud olla, kui inimkond poleks leiutanud elektripirne, sisepõlemismootorit ega arvutit. Tapinase Vilnius on Allianssi vabalinn, mille juudid Vene impeeriumilt välja ostsid, progressi, teaduse ja müstika keskus, kus asju ajavad alkeemikud ja linna kohal lendavad dirižaablid. Autor kasutab traditsioonilisi detektiivžanri võtteid, et luua alternatiivne Vilniuse tõelisus.

Mäng päriselu ja fantaasia seostega on kohati üsna vaimukas. Tegelaskuju Jonas Basanavičiuse nimi seostub eelkõige Leedu taasiseseisvumisega 16. veebruaril 1918. aastal. Kui sajandivahetusel korraldati netihääletus, et leida XX sajandi 100 kõige mõjukamat leedulast, siis sai Basanavičius kõige enam hääli ja teda austati nimetusega „rahva isa”. Tapinase romaanis on Basanavičius aga veidrikust teadlane, alkeemik, kes on leiutanud vehklevate 
tiibadega lennumasina - ornitopteri - ning hirmutab sellega lennates linnaelanikke. Autor ei eelda lugejalt Leedu ajaloo tundmist (see lisab omamaise lugeja jaoks vaid pisut vürtsi juurde) ja romaani tõlgitakse juba inglise ja poola keelde. Tekst on intrigeeriv, enam kui viiesajal leheküljel põimuvad kolm peamist süžeeliini: vandenõu (välismaised jõustruktuurid organiseerivad Vilniuses toimuva tippkohtumise ajaks rahutusi), rööv (mõjukate isikute hoolealuse Mila, üleloomulike võimetega neiu varjamine vaenlaste eest) ja saladus (tapmised ja salajoonised).

Ka kõik selle raamatuga seonduv on pisiasjadeni läbi mõeldud. Teist korda leedu kirjandusloos pärast Sabaliauskaitè „Silva Rerumit” turundati ja reklaamiti raamatut väga läbimõeldud strateegia alusel. Romaani avalik esitlus toimus Leedu taasiseseisvuspäeval Vilniuse ülikooli teatri saalis. Samal päeval toimus Vilniuse vanalinnas orienteerumismäng „Kadunud teadlase saladus”. Raamatule loodi põhjalik kodulehekülg (http://www.vilkovalanda.lt), lisaks on romaani ainetel loodud videomäng „Howler” (autor A. Marcelionis), mis on saavutanud erakordse populaarsuse. Ja korralik turundus kandis vilja: raamatu esimene tiraaž müüdi läbi raamatumessi esimestel päevadel.

\section{Valus lähiajalugu}

Leedu lähiaastate kirjanduses nähakse tendentsi, et kirjaniku päästerõngaks saab aines. Tekstile annab lisaväärtuse uudsus - konkreetset materjali pole varem üldse või siis piisaval tasemel esitatud. Leedu poeet, tõlkija ja esseist Eugenijus Ališanka ütleb oma esseeraamatus "Gatvè tarp dviejų bažnyčių” („Tänav kahe kiriku vahel”, 2012): „Mul pole vaja teemat, inspiratsiooni ega fantaasialendu. Mul on vaja materjali. Kõik muu tuleb hiljem. Kui on vaja" (Ališanka 2012: 97). Ühe unustuse hõlma vajunud või ka tahtlikult unustatud peatüki Leedu ajaloost toob esile 2012. aasta parimaks raamatuks tituleeritud Alvydas Šlepikase (snd 1966) romaan „Mano vardas - Maryte” („Minu nimi on Maryte”", 2012). Autor on avaliku elu tegelane, kes on lõpetanud Leedu muusikaakadeemia näitleja ja lavastaja eriala ning töötanud mõlemas ametis, lisaks on ta ühe populaarsema Leedu algupärase telesarja „Nekviesta meile”” („Kutsumata armastus”, 2007-2009, jätkus 2010. aastal teise nime all) stsenarist. Kirjanduses debüteeris ta 1994. aastal, on kahe luule- ja ühe novellikogu autor, kuid siiani suurima tunnustuse on saanud just viimase romaani eest. Sel sügisel anti välja juba neljas trükk, kogutiraaž 10000 eksemplari.

Autor on öelnud: „Selle raamatu teema justkui leidis mu ise üles. Filmirežissöör Jonas Marcinkevičius tegi 1996. aasta paiku mulle ettepaneku teha dokumentaalfilm saksa lastest, kes sõjajärgseil aastail otsisid pääsemist Leedust. Siis kuulsin esimest korda saksakeelset sõna Wolfskinder - hundilapsed" (Šlepikas 2012a: 180). Sõjajärgsest Ida-Preisimaa koloniseerimisest NSVL-i poolt ja eriti saksa orbude (hundilaste) saatusest on seni Leedus vähe räägitud. Teema oli selleks liiga valus - kerjavad nälginud lapsed ja piiriäärsete leedulaste dilemma (saksa lapse aitamise või oma koju võtmise eest ähvardas Siberisse saatmine). Kohtumisel lugejatega rääkis Ślepikas sellestki, kuidas ta romaani jaoks materjali kogus ning intervjueeris omaaegseid „hundilapsi”, kes Leedus üleskasvanuna sageli ei tea oma tegelikku päritolugi, ning kuidas üha enam sai selgeks, et ta peab nende saatusest kirjutama. 
Romaanis on kujutatud ühe saksa pere saatust Preisimaal ning peretütre Renate kohutavate eksirännakute lugu. Kuigi mitmed kriitikud on väitnud, et raamat ei vääri romaani nimetust, vaid on pigem üksikstseenidest koosnev filmistsenaarium, siis just tänu sellele on autoril onnnestunud luua emotsionaalselt nii mõjus ning sündmustikult tihe teos. Autor väldib nii õudustega ülepingutamist kui ka liigset pisardamist, on väga lakooniline, fragmentaarne, kasutab palju pause. Tekib tõesti filmilik kogumulje, kaadrid vahetuvad kiiresti ja hoiavad pinget. Pigem heidaksin ette romaani lõppu, mis muutub tavapäraseks sirgjooneliseks jutustuseks. Raamatu stiili kohta on autor öelnud: „Otsisin katkendlikku rütmikat, nagu räägiks nuuksuv laps” (Šlepikas 2012b: 127). Samuti ei häbene ta tunnistada, et pidas kirjutades silmas auditooriumi. Kuna teema tundus talle endale nii oluline, seadis ta eesmärgiks jõuda võimalikult paljude lugejateni ning valis seepärast filmistsenaariumliku kirjutamislaadi, et ka infoühiskonnas üles kasvanud teismeline suudaks raamatut lugeda. ${ }^{1}$

Tundub juba seaduspärana, et iga kümne aasta tagant puhkeb leedu avalikkuses tõsisem kirjandusega seotud skandaal. Kuna järgmisena vaatluse alla tulev kirjanik, juba elava klassiku tiitli pälvinud Sigitas Parulskis (snd 1965), võttis mõlemal eelneval korral sõna süüdistatavate kaitseks ning tema viimasest romaanist on saamas selle kümnendi (senine) skandaal, tutvustan lühidalt kaht varasemat. 1990. aastatel sai uskumatult tulise vastuvõtu osaliseks Jurga Ivanauskaitè (1961-2007) romaan „Ragana ir lietus” („Nõid ja vihm”, 1993) - Vilniuse omavalitsus keelas selle romaani müügi linna raamatupoodides ohtrate pornograafiliste stseenide pärast. Ajakirjanduse ja Vilniuse linnavalitsuse vahelise pool aastat väldanud diskussiooni tulemusena keeld siiski tühistati. Skandaalne romaan pälvis aga rahvusvahelise tunnustuse. Neli aastat hiljem ilmus see Mihkel Looduse tõlkes ka eesti keeles ning Mait Talts (1997) kirjutas oma retsensioonis: „Eestis poleks see isegi tollal skandaali tekitanud, seda enam siis praegu [---] Leedus tookord puhkenud skandaali tagamaad jäävad tunduvalt liberaalsemale eestlasele enamasti arusaamatuks." Kuigi elame üsna sarnases kultuurikeskkonnas, erinevad meie ja leedulaste mõttemaailmad ometi suuresti. Nii et Leedu katoliiklikku ühiskonda šokeerinud romaan oli omamoodi teerajaja, sest suutis Parulskise sõnul murda kaks olulisimat tabu: „[R]eligioon ja seks on tõepoolest alati olnud peaaegu suurimad tabud meie ühiskonnas” (Parulskis 1994: 5).

Teiseks suureks skandaaliks andis ainest Marius Ivaškevičiuse (snd 1973) teine romaan „Žali” („Rohelised”, 2002), mis laveerib ajalooliste faktide ja fiktsiooni piiril. See on lugu Leedus pärast Teist maailmasõda puhkenud metsavendade sõjast. Ivaškevičius, kes on romaani protagonistiks valinud reaalselt eksisteerinud inimese, modelleerib kunstiliselt situatsioone ja sündmusi, püüdes aru saada selle sõja mõttest, avab sõja teise - igapäevase poole. See on värske vaade valusatele minevikusündmustele. Võib julgelt väita, et see metsavendade juhist Jonas Žemaitisest ${ }^{2}$ rääkiv romaan tekitas kogu Leedu avalikkuses erakordse vastukaja. Keelustamiseni küll ei mindud, kuid

${ }^{1}$ Olgu veel öeldud, et 2012. aastal ilmus eesti keeles kolme naise mälestusteraamat „Königsbergi naised 1945-1948" (saksa keelest tõlkinud Anne Rekkaro), mis annab ettekujutuse Ida-Preisimaad ja selle elanikke tabanud kohutavast saatusest.

2 Jonas Žemaitis (1909-1954) - Leedu metsavendade relvastatud jõudude juht ja organisaator, kogu vastupanuliikumise koordinaator; 2009. aasta 11. märtsil, Leedu taasiseseisvumispäeval kuulutati ta postuumselt neljandaks Leedu Vabariigi presidendiks. 
poleemika tulisus oli „Nõia ja vihma” omaga samaväärne. Romaani ründasid kõik, alustades endistest poliitvangidest ja lõpetades kirjanike liidu liikmetega. Kuigi autoril polnud see kavas, tõi romaan päevavalgele ühe peidus olnud tabu: enam ei puhke skandaale seksistseenide pärast nagu kümme aastat varem, kedagi ei häiri ka kiriku ja preestrite kujutamine, kuid lähiajalugu ja selle kangelased on õrn koht. Eriti pühad ja puutumatud on metsavennad, keda Leedus käsitletakse lausa ebajumalatena.

Nüüd aga XXI sajandi teise kümnendi kirjanduslikust skandaalist, mille põhjustaja on omaette nähtus leedu nüüdiskirjanduses - Sigitas Parulskis, poeet, esseist, dramaturg ja kriitik, kelle kontol hetkeseisuga 19 raamatut, neist viis romaani. Teda on pärjatud kõigi olulisemate preemiatega. Juba tema esikromaan, osalt autobiograafiline „Trys sekundès dangaus” („Kolm sekundit taevast”, 2002) pälvis 2004. aastal Leedu kirjanike liidu preemia, samuti on kirjanduskriitikud selle tituleerinud tema põlvkonna kultusraamatuks. Selles väitis Parulskis, et kuulub „põlvkonda, kellel pole mingeid erilisi tundemärke, kes on peaaegu omadusteta" (Parulskis 2002: 8). 2004. aastal omistati talle ka Leedu kõrgeim autasu - rahvuspreemia - novaatorliku kirjandusloomingu eest, mis ühendab endas erinevaid ühiskondlike ja individuaalsete kogemuste kihistusi, samuti stiiliuuenduste eest. Lisaks valisid lugejad tema esseekogu „Sraigė su beisbolo lazda” („Tigu pesapallikurikaga”, 2006) 2007. aastal parimaks raamatuks. Parulskis on ka enim võõrkeeltesse tõlgitav tänapäeva leedu kirjanik. Võiks öelda, et tema raamatukaanele trükitud nimi käitub lausa omaette kaubamärgina, kindlustab juba ette lugejate huvi ning kriitikute soosingu.

Kuidas saab selline austusväärne kirjanikuhärra tekitada skandaali? Kirglikke diskussioone põhjustab tema seni viimane romaan „Tamsa ir partneriai” („Pimedus ja partnerid”, 2012), täpsemalt küll selle teema ja esituslaad. Lühidalt öeldes on Parulskist süüdistatud holokausti teema ärakasutamises, inimlike kannatuste labastamises, ajaloolise tõe väänamises ja pornograafias. On võrreldud dokumentalistikat, autentseid mälestusi ning Parulskise teksti ja väidetud, et talle on olulised vaid mahlakad detailid ja efektid (Kvietkauskas 2013: 12), lugeja hollywoodlik mõjutamine. Samuti on ette heidetud peategelase passiivsust ja autoripoolse selge hinnangu puudumist. Kriitikaga tuleb vähemalt osaliselt nõustuda. Juba enne kõnesoleva romaani ilmumist on näiteks noorkriitik Mindaugas Grigaitis (2013) muuhulgas öelnud, et kirjanik põeb „kehvveresust” või siis „stiili aneemiat” ning on oma ande toodangu hulgale ohvriks toonud. Päris asjatud pole need sosinad kindlasti. Romaan tundub lugedes kohati tehislik ning novaatorlikkust näib asendavat teadlik brutaalsete vägivallaaktide või seksistseenidega liialdamine. Kuid kindlasti väärib tunnustust Parulskise oskus valida aktuaalseid, delikaatseid teemasid ning neid ilukirjanduse kaudu tõstatada. Sel korral on tegemist lihtsalt eriti hella teemaga - leedulaste osalus Teise maailmasõja juutide massihävitamises. Holokaustist ja sellega seoses ka leedulaste valgustkartvatest tegudest on räägitud ja kirjutatud varemgi, kuid see teema pole pälvinud nii suurt tähelepanu. Olgu muuhulgas öeldud, et septembri alguses 2013 omistas Sugihara fond Parulskisele tolerantsuse preemia.

Eelmise ja selle kümnendi skandaalid on niisiis olemuselt küllalt sarnased, seotud lähiajaloo interpreteerimise, hindamise ja analüüsiga. Ivaškevičiuse ja Parulskise skandaalsete romaanide tugevuse, missioonina on esile toodud 
oskust hinnata ajaloosündmusi inimese silmade läbi, inimestada Leedu lähiajalugu. Noorkriitik Urtė Sakalytė (2013) on tabavalt öelnud, et see on „mitte ainult fantaasiamäng, vaid teatav teadvuse hügieen".

\section{Hiina invasioon ja kultuur}

Kahel viimasel aastal on leedu kirjanduses avaldunud veel üks kummaline kokkusattumus: suhteliselt lühikese aja jooksul on lausa kolm leedulannat avaldanud kirjandusteose, mille ühisosaks Hiina aines. Oma muljed ja kogemused aastasest Pekingis õppimisest ja reisidest dokumenteeris ning valas päeviku vormi Vaiva Grainytè (snd 1985). Nii sündis lugejate hulgas suure menu osaliseks saanud raamat „Pekino dienoraščiai: esè” („Pekingi päevaraamat: essee”). 2012. aastal kuulus see viie teose hulka, mis pretendeerisid aasta parima raamatu tiitlile. Samuti on žurnalistliku kirjanduse esindaja, ajakirjanik Audronė Urbonaitè (snd 1955) teine romaan „Cukruota žuvis” („Suhkrukala”, 2012) algtõuke saanud Taivanist, kus ta kuus aastat tagasi pool aastat tervislikel põhjustel viibis, külastades ka Hongkongi. Urbonaitè romaani teemaks on hiinlaste invasioon Euroopasse ja Leetu, globaliseerumine, mis tungib 50-aastase ajakirjaniku ellu: poeg jätab emale oma lapse, kelle hiinlannast ema kaob. Autor tõstatab siin identiteedi probleemi: kas erinevatest rahvustest vanemate lapsed teavad, millise kultuuri esindajad nad tahavad olla, kas nad suudavad tutvuda sellega, mis on veel alles balti kultuurist. Kriitikute hinnanguil on teose kunstiline väärtus küll kaheldav, aga sisu aktuaalne provintslikes leedulastes peab kasvatama tolerantsi.

Kolmanda autori, Undinè Radzevičiūtè (snd 1967) puhul rõhutavad kriitikud läbivalt, et autor jääb leedu kirjanduse traditsioonist täiesti väljapoole. Radzevičiūtè peamiseks kirjutamise impulsiks on idee, mitte lugu, tegemist on intellektuaalse proosaga, kus kõik on pedantselt läbi mõeldud, stiil puhastatud ilutsemisest. Igas teoses ütleb ta midagi olulist inimeste pahede, tema enda sõnul „inimeste saladuste kohta”, mida nad ise ei tahaks avalikustada. Samuti eristub ta teistest leedu kirjanikest oma huumoritunnetuse, inglasliku eneseiroonia poolest. Radzevičiūtèt on nimetatud leedu musta huumori meistriks. Askeetliku sõnakasutuse pärast on tema looming ära teeninud määratluse „akupunktuurne”. Tegemist on isikuga, kes loob enda ümber mõnetise salapära: ta peaaegu ei anna intervjuusid ja väldib internetis enda kohta ükskõik missuguse info avaldamist. Autor ei ole väga produktiivne, tema kirjanduslik debüüt oli kümme aastat tagasi ja teine lühiromaan ilmus pärast seitsmeaastast pausi. 2011. aastal avaldas ta esseekogu ning 2013. aastal juba mahuka romaani „Žuvys ir drakonai” („Kalad ja draakonid”). Nii esseekogu kui ka viimase romaaniga on ta pretendeerinud aasta parima raamatu tiitlile. Audrius Ožalas (2013) avaldas pärast romaani ilmumist retsensiooni, mida alustab vägagi ülistavalt: „Aasta alles algas, aga meil on juba raamat, mida aasta lõpus ilma mingi kahtluseta nimetatakse üheks huvitavamaks, originaalsemaks leedu kirjandusteoseks."

Raamatus on kaks peamist, paralleelselt kulgevat süžeeliini. Üks hargneb XVIII sajandi Quingi dünastia valitsusaja Hiinas, kuhu saabub jesuiidist misjonär isa Castiglione (Kastiljonè) ülesandega maalida fresko katoliku kirikusse ja kui kirikut pole, siis koos teiste vendadega kirik ehitada. Teine 
leiab aset tänapäeval kuskil korteris. Kuigi riiki ega linna pole kordagi täpsustatud, on selge, et see on Vilnius. Konkreetne linn polegi eriti tähtis, sest korter etendab teatrilava funktsiooni, kus teravate dialoogide kaudu avatakse nelja korterielaniku omavahelisi suhteid. Need neli on vanaema Amigorena, erootilisi romaane kirjutav ema Nora ning tütred Šaša ja Miki, kes jälgivad läbi akna lähedusse elama asunud hiinlaste elu. Nende vestlused on teravad, iroonilised, igal sõnal on kaal, suhtlus läheneb verbaalsele kahevõitlusele. On nii situatsioonikoomikat kui ka absurdi. Vanaema jälgib läbi akna hiinlasi ja loendab neid (chinatown on selles nimetus linnas enam kui tagasihoidlik, Hiina saatkonna vastas elav vanaema näeb iga päev vaid kolme hiinlast), kirjutab kirju politseile, kurjustab järgemööda kõige ja kõigi üle.

Radzevičiūtè tegelaskujud ei allu kategoriseerimisele, ei vasta stereotüüpidele, neid pole võimalik lõpuni mõista, tegelaste karakterid avanevad tegevuste ja dialoogide kaudu, pole staatilisi kirjeldusi. Kirjanikule omane maneer - vähe sõnu ja palju sisu (eriti peidetud) - aeglustab lugemist. Filosoofilisel ja olmelisel tasandil hargnevad arutlused universaalsetel teemadel: inimeste ja rahvuste saatus, erinevate kultuuride ja tsivilisatsioonide kokkupuuted, samuti peresuhted, popkultuur, usk, kutsumus, vabadus ja vastutus. Kui raamatu avaldanud kirjastuse vanemtoimetaja Saulius Repečka leidis teose esitlusel, et „raamat on mõeldud lugejale, kes oskab ära tunda tõelise kirjanduselu sündmuse ja oskab eristada seda lihtsalt mullikeste ajamisest [---] vanematele kui 25-aastastele, eriti neile, keda vähemalt natukegi huvitab orient, kellele on lähedane idamaade tarkus ja kunst. See on raamat haritud lugejale, kellele meeldib lugeda aeglaselt, teksti nautides, kes ei oota raamatust vaid meelelahutust" (Repečka 2013), siis on esile toodud ka seda, et kohati jääb mulje, nagu eelistaks stiilimänge armastav autor vormi sisule ning raamat võib üsna suurele hulgale lugejatest tunduda siiski liiga „imelik”. Kuid Radzevičiūtè looming on alati tekitanud kaks leeri: tal on arvestatav hulk kirglikke fänne, kes pikisilmi ootavad iga uut raamatut, ning ka kindlameelsed kriitikud, kes väidavad, et kirjanik loob poolikuid teoseid.

\section{Leedu suur euroromaan?}

Leedu kultuuriajakirjandust lugedes jääb aeg-ajalt silma mõiste „euroromaan”, mille all peetakse silmas leedulase kirjutatud suurt läbimurderaamatut, mis suudaks rahvusvahelisel areenil mõistmist ja lugejaid leida. Ootus ja lootus on suur. Ühe võimalusena tuleks ehk kõne alla Ameerikas sündinud, kasvanud ja elava, inglise keeles kirjutava Rūta Šepetyse (snd 1967) esikromaan, 2011. aastal Ameerikas ilmunud „Between Shades of Gray” (samal aastal ilmus tõlge leedu keelde „Tarp pilkų debesų”). Mõneti võib raamatule Leedus osaks saanud vastakat vastuvõttu võrrelda Sofi Oksaneni romaani „Puhastus” ümber tekkinud diskussiooniga Eestis. Paralleele võib leida ka teoste vastuvõtus laias maailmas. Šepetyse romaani saatis lausa uskumatu tunnustustelaine (sh The New York Timesi bestsellerite nimekirja jõudmine; vt www.rutasepetys.com) ja lugejamenu: see on tõlgitud 27 keelde ning seda on levitatud 43 riigis. Itaalias on raamat lisatud koolide soovitusliku kirjanduse nimekirja, USA 20 osariigis lausa kohustuslike raamatute hulka. 
Lugu ise on Balti riikide elanikele valuliselt tuttav: 15-aastane Lina valmistub 1941. aastal kunstiõpinguteks, esimesteks kohtinguteks ja muudeks suverõõmudeks. Kuid ühel ööl tungib majja Nõukogude salateenistus, Lina viiakse koos ema ja vennaga Siberisse. Perest lahutatud isa saadetakse vanglasse surema. Romaani luues tugines Šepetys paljuski küüditatute jutustustele. Raamatu sihtrühmaks on autori sõnul teismelised ja noorukid. Vastuolulisi hinnanguid ilmestab kaks poolust. Ühelt poolt on autorile Leedus ette heidetud banaalsust, massidele suunatud lihtsustamist, kohati lausa valetamist (eksimist ajaloolise tõe vastu) ja inimeste kannatuste hollywoodistamist. Teisalt omistati romaanile 2012. aastal Leedu kaitseministeeriumi ja Leedu kirjastajate assotsiatsiooni poolt välja antav Patrioodi preemia ning 2013. aasta 6. juulil, Leedu riikluse päeval (1253. aastal krooniti siis Leedu suurvürstiriigi looja, esimene ja ainus kuningas Mindaugas) andis Leedu president Dalia Grybauskaitė Šepetysele üle riikliku teenetemärgi Leedu riigile osutatud teenete ja Leedu nime populariseerimise eest maailmas. Vahetult enne preemia kätteandmist sai teatavaks, et raamat ekraniseeritakse Hollywoodis. 2013. aastal jõudis lugejateni ka autori teine romaan „Out of the Easy” (leedu keeles „Nelengvu keliu”), mis räägib elust 1950. aastate New Orleansi prantsuse kvartalis.

\section{Normaalne}

Üsna ootuspäraselt on leedulased hinnangutes oma kirjandusele pigem skeptilised ning kriitikud esitavad aina sagedamini küsimust „Kas kirjutada võib tõesti igaüks?", vihjates sellega viimaste aastate valdavale poleemikale: mis on väärt- ja mis massikirjandus? On kasutatud ka liigitust neliteratura ('mittekirjandus') või siis jutukas, naistekas jne. Sellise n-ö žurnalistliku kirjanduse pealetungi Leedus on tutvustanud Mihkel Loodus (2009). Kirjandusteadlane Regimantas Tamošaitis (2008: 56) on popkirjanduse lokkamist võrrelnud koguni Sosnovski karuputke pidurdamatu levikuga. Teisalt on see mõistetav ja seletatav lugeja sooviga saada kiirelt ja kerge vaevaga kätte lugemisnauding, näha oma argielu peegeldust ning saada vastuseid, samas kui n-ö tõsine kirjandus esitab küsimusi. Leedu kirjandusmaastikelgi vohavad Tuhkatriinulood mõjuvad lugejaile nagu usk, inimesed vajavad muinasjutte.

Kuid siiski võib tõdeda, et leedu kirjanduses on olukord normaalne, isegi hea, igal aastal ilmub palju uudisteoseid, teiste hulgas üsna häid. Kirjutamist jätkavad juba tuntud ja tunnustatud autorid, aga lisanduvad ka uued nimed. Teemadering on lai, huvitav ja mitmekülgne. Lugemisväärset leiab igasuguste huvidega lugeja. Tekkimas on tasakaal trauma- ja mängulise kirjanduse vahel. Nüüdisaegse leedu kirjanduse tugevust või normaalsust kinnitavad kindlasti ka tõlked teistesse keeltesse ning mitmed rahvusvahelised auhinnad. Näiteks on leedu kirjanikele kahel korral omistatud Euroopa Liidu kirjandusauhind. Esmakordsel preemiate väljakuulutamisel 2009. aastal pälvis teiste hulgas tunnustuse Laura Sintija Černiauskaitè (snd 1976) esikromaani „Kvèpavimas i marmurą” („Marmorisse hingamine”, 2006) eest. Sama tunnustuse vääriliseks peeti 2012. aastal teistki leedu naiskirjanikku Giedra Radvilavičiūtèt (snd 1960). Preemia sai ta esseekogu „Šiąnakt aš miegosiu prie sienos” („Täna magan ma seina ääres”, 2010) eest. Kogu valiti Leedus 2010. aasta viie parima raamatu hulka, kuid esimeseks siiski ei tõusnud. 
Kirjandus ja kriitika on ühe mündi kaks poolt, hinnanguid ootavad nii autorid kui ka lugejad. Paljude leedu kirjandusteadlaste arvates on praegune leedu akadeemiline kirjanduskriitika nõrk. Kuigi väidetakse, et nooremad autorid avaldavad peamiselt muljekriitikat ning retsensioone kirjutatakse enamasti sõpradele ja nii on kujunenud olukord, et kirjanikud kirjutavad üksteisest ega lase sellesse siseringi kedagi võõrast, siis väljast vaadates ei tundu olukord nii troostitu. Leedus ilmub mitmeid arvestatavaid kultuuriväljaandeid, kus muuhulgas pööratakse tähelepanu kirjanduselus toimuvale. Eraldi väärivad esiletoomist kaks Leedu kirjanike liidu väljaannet: algul mainitud kuukiri Metai, mis hakkas ilmuma 1942. aastal, ning 1946. aastal trükivalgust näinud nädalaleht Literatūra ir menas (Kirjandus ja Kunst, meie Sirbi analoog). Leht läbis 2012. aastal uuenduskuuri, muutudes nädalalehest nädalaajakirjaks, vähendati formaati ning hakati rohkem tähelepanu pöörama kvaliteetsetele illustratsioonidele. Kui varem võttis üsna palju leheruumi jooksev päevakajaline info, nt teatrite mängukavad, näituste reklaamid, lühikesed raamatututvustused, siis nüüd on tegemist arvestatava, tõsiseltvõetava kultuuriväljaandega, mille 46 leheküljest vähemalt kolmandik on pühendatud kirjandusele. Ilmuvad nii leedu kui tõlkekirjanduse katkendid, kriitika, ülevaated, raamatututvustused. Kindlasti on positiivne mõju kirjanduse arengule Leedu kirjanduse ja rahvaluule instituudi initsiatiivil 2012. aastal loodud kirjanduskriitikutele mõeldud Vytautas Kubiliuse nimelisel preemial.

Lõpetuseks üks meeleolukas, aastaaega sobiv hinnang tänapäeva leedu kirjanduse kohta kirjanduskriitiku ja -teadlase Jūratė Sprindytė (2006: 27) sulest: „Leedu kirjandus on kontrastne nagu Leedu talv - lörts, käre pakane, sula, härmatis, sula ja külm korraga ja jälle kõik algusest peale” ehk siis normaalne - eluterve ja arenev.

\section{Kirjandus}

A l i š a n k a, Eugenijus 2012. Gatvė tarp dviejų bažnyčiu. Vilnius: Tyto alba.

A m b r a z e vi či u s, J. 1937. Vormi probleem leedu uues kirjanduses. - Looming, $\mathrm{nr} 4$, lk 452-456.

B e r e s n e vi č i u s, Gintaras 2002. Ant laiko ašmenų. Vilnius: Aidai.

Grigaitis, Mindaugas 2013. Apie istoriją literatūroje. - KaMaNe.lt, 17. VI, http://www.kamane.lt/Kamanes-tekstai/Literatura/Apie-istorija-literaturoje (10. XII 2013).

J a bl o n s k a i t è, Dovilè 2012. Apie Vilnių lyg apie mylimaji:: „Jo grožis svaigina, dèl jo bėdu nuolat skauda": [pokalbis su meno istorike, rašytoja Kristina Sabaliauskaitè / parengè]. - Vilniaus diena 7. I.

J u r či uk o n y tè, Agnè 2009. Kristina Sabaliauskaitè Silva Rerum. - Naujien Laiškis, $\mathrm{nr} 1$, lk $1,4$.

K u bi l i u s, Vytautas 2004. Ajaloolise proosa vägi. [Tlk Danutė Sirijos Giraitė.] Looming, nr 2, lk 295-296.

Kvi etkauskas, Mindaugas 2013. Sąžinès balsas ar holokausto industrija? Literatūra ir menas 22. II.

L o o d u s, Mihkel 2009. Leedu žurnalistlik romaan ja neliteratūra. - Looming, nr 6, lk 875-877.

M a či a n s k a i tè, Loreta 2010. Išsisèmusi kančia: lietuvių romano dinamika pirmuoju nepriklausomybės dešimtmečiu. - Colloquia, $\mathrm{nr} 24$, lk 113-128. 
O ž a l a s, Audrius 2013. Knygos recenzija. Undinės Radzevičiūtès žuvys, virstančios drakonais. - 15min.lt, 6. IV, http://www.15min.lt/naujiena/kultura/ literatura/knygos-recenzija-undines-radzeviciutes-zuvys-virstancios-drakonais-286-323219 (10. XII 2013).

P a r u l s k i s, Sigitas 1994. Nauja žodžio mitologija lietuvių literatūroje, arba pastebejjimai apie kūrèjo ir kūrinio būklè dabartinèje Lietuvoje. - Nemunas, nr 4, lk 4-6.

P a r u lski s, Sigitas 2002. Trys sekundès dangaus. Vilnius: Baltos lankos.

R e p e čka, Saulius 2013. Naujoje Undinès Radzevičiūtès knygoje - Rytų ir Vakaru difuzija. - Baltos lankos, http://baltoslankos.lt/lt/pasleptas-meniu/zuvysir-drakonai (10. XII 2013).

S a k a ly tè, Urtè 2013. Apie istoriją literatūroje. - KaMaNe, 17. VI, http://www. kamane.lt/Kamanes-tekstai/Literatura/Apie-istorija-literaturoje (10. XII 2013).

Samalavičius, Almantas 2010. Peaaegu normaalne. - Vikerkaar, nr 7/8, lk 117-122.

S p r i n d y tè, Jūratė 2006. Žiemos skaitiniai. - Šiaurès Atènai 18. III.

Šle pikas, Alvydas 2012a. Mano vardas - Marytè. Vilnius: Lietuvos rašytoju sajungos leidykla.

Šl e pi k a s, Alvydas 2012b. Už horizonto pasaulis nesibaigia. Rašytojas Alvydas Šlepikas atsako i Herkaus Kunčiaus klausimus. - Metai, nr 8-9, lk 123-129.

T a m o š a i t i s, Regimantas 2008. Populiariosios literatūros suvešẻjimas. Solveiga Daugirdaitè, Loreta Jakonytė, Laimantas Jonušys, Jūratė Sprindytė, Regimantas Tamošaitis. - Metai, nr 10, lk 73-87.

T a m o š a i t i s, Regimantas 2013. Literatūra tarp dramos ir žaidimo, arba Ar tikrai „rašyti gali kiekvienas”? 2012-ųu knygos. - Metai, nr 4, lk 69-87.

T a lt s, Mait 1997. Leedukas pole eestlane. - Eesti Päevaleht 5. IX, http://www. epl.ee/artikkel/23348 (10. XII 2013).

$\mathrm{V}$ a b u o l a s, J. 1993. Vilnius kaip pasaulio metafora. I klausimus atsako rašytojas Ričardas Gavelis. - Nemunas, nr 10, lk 6-7.

\section{Pain and game in the Lithuanian novel of the teens of the $21^{\text {st }}$ century}

Keywords: Lithuanian literature, contemporary literature, prose survey

A survey is given of the Lithuanian novel of the past five years. Side by side with poetry, which the Lithuanians are traditionally famous for, their recent prose has considerably advanced for diversity. A growing awareness of the importance of book marketing must have increased reader interest in home-grown prose.

The literary image of the capital of Lithuania has gained some new strata. The action of the family novel Silva Rerum (2008-2011) by Kristina Sabaliauskaite takes place in the 17 st-18st-centry Vilnius. Andrius Tapinas in his novel Vilko valanda („The Hour of the Wolf”, 2013) has invented a steampunk Vilnius reminiscent of the town in the early 1900s. Gina Viliūne’'s mystery novel Karūna be karaliaus („A Crown Without a King”, 2012) keeps shuttling between today and various historical times.

Recent history has become especially popular, enabling discussion of some sensitive areas or topics not previously covered. The novel Mano vardas - Maryte 
(„My Name Is Maryte”, 2012) by Alvydas Šlepikas tells about the fate of German orphans, the so-called wolf children after the Soviet colonization of Eastern Prussia. Sigitas Parulskis, already a living classic known for his apologia for scandalous books has created a scandal of his own by publishing the holocaust novel Tamsa ir partneriai („Darkness and Partners”, 2012).

Surprisingly, several China-themed novels appeared at a short interval, Undinè Radzevičiūtè's Žuvys ir drakonai („Fish and Dragons”, 2013) being the most distinctive of those. Previously, great expectations of a Euro novel bringing an international breakthrough had been expressed, however, in connection with „Between Shades of Gray” (Tarp pilku debesu) published in 2011 by Rūta Šepetys, who lives and works in the United States.

Despite the complaints over entertainment or even non-literature flooding the Lithuanian literary landscape, a process sometimes even compared to the rampant spread of the notorious Sosnovski hogweed, the overall situation can be regarded as normal - criticism is active, literary magazines are published and Lithuanian literature is alive and kicking.

Tiina Kattel (b. 1971), MA, University of Tartu, Institute for Cultural Research and Fine Arts, Chair of World Literature, doctoral student; Language Centre, acting head and lecturer; translator, tiina.kattel@ut.ee 